\title{
Replacement of Regular Salt by a Novel Salt Alternative Improves the Cardiovascular Effects of the ACE Inhibitor Enalapril
}

\begin{abstract}
Eero M.A. Mervaala*, Juha T. Laakso*, Jaakko-Juhani Himberg ${ }^{* * *}$, and Heikki O. Karppanen*
The present high levels of sodium chloride (regular salt, RS) intake interfere with the therapeutic effects of angiotensin converting enzyme inhibitors. In previous studies a novel potassium-, magnesium- and Ilysine-enriched and sodium-reduced salt alternative (SA) has been virtually devoid of the hypertensive, left ventricular hypertrophy producing, and life-span shortening effects, characteristic of RS. We therefore compared the influence of SA on the cardiovascular effects of enalapril with that of RS in male stroke-prone spontaneously hypertensive rats (SHRSP). During the 28-day experiment, RS alone produced a marked rise in blood pressure, induced remarkable left ventricular hypertrophy, and caused the death of five out of 18 SHRSP. Oral enalapril treatment did not significantly affect either of the detrimental cardiovascular effects of RS but there were no deaths in the enalapril-treated group. The SA supplemented diet neither caused mortality nor induced any significant rise in blood pressure as compared to control SHRSP, and caused significantly less cardiac hypertrophy than RS. During SA, enalapril had a marked antihypertensive effect and it also completely blocked the salt-induced left ventricular hypertrophy. During SA + enalapril or SA alone, there was no tendency to hyperkalemia in any of the SHRSP. There was not any difference in the plasma renin activity (PRA) between control, RS and SA groups. Enalapril increased PRA to the same extent, approximately three-fold, in the RS and in the SA supplemented SHRSP. Hence, PRA does not explain the marked improvement of the effects of enalapril by $\mathrm{SA}$ in comparison to RS. Our findings suggest that replacement of regular salt by the novel salt alternative may remarkably improve the cardiovascular effects of enalapril treatment. (Hypertens Res 1994; 17: 59-69)
\end{abstract}

Key Words: enalapril, stroke-prone spontaneously hypertensive rats, cardiac hypertrophy, renin, sodium, potassium, magnesium

Angiotensin converting enzyme inhibitors (ACEIs) belong to the first-line drugs in the treatment of arterial hypertension and congestive heart failure. Unfortunately, the high levels of sodium chloride (regular salt) intake, typical for most industrialized societies (1), interfere with the therapeutic effects of ACEIs. Therefore, salt restriction or natriuretic diuretics are frequently used to improve the therapeutic efficacy of ACEIs (2).

Increased intake of potassium exerts antihypertensive effects and protects against stroke (3-5). Increased intake of magnesium may also, in some cases, reduce blood pressure and produce a variety of other favorable cardiovascular and metabolic effects (6-9).

Even without drug treatment, reduction in the intake of sodium chloride produces an antihypertensive effect $(1,10-12)$. In our recent studies, a novel potassium-, magnesium-, and 1-lysine-enriched salt alternative, even in high doses, did not raise blood pressure and produced little if any left ventricular hypertrophy in SHR, whereas such harmful cardiovascular effects were characteristic of regular salt (13). The novel salt alternative is increasingly used instead of regular salt both in home kitchens and by the food industry (14). Hypertensive patients, including those receiving antihypertensive drugs, are particularly likely to replace the use of regular salt by the salt alternative. We therefore undertook this study to examine possible beneficial or harmful interactions of the ACEI enalapril with the salt alternative. Using stroke-prone spontaneously hypertensive rats as a model, we studied the effects of enalapril during salt alternative or regular salt supplementation on blood pressure, left ventricular hypertrophy and plasma electrolyte levels. The

From the ${ }^{*}$ Department of Pharmacology and Toxicology, University of Helsinki, Finland. ${ }^{* *}$ Mila Ltd., Helsinki, Finland. ${ }^{* * * *}$ Department of Clinical Pharmacology, University of Helsinki, Finland.

This study was supported by grants from the Academy of Finland, the Yrjö Jahnsson Foundation and the Sigrid Jusélius Foundation.

Address for Reprints: Eero Mervaala, M.D., Department of Pharmacology and Toxicology, University of Helsinki, P.O. BOX 8 (Siltavuorenpenger 10), FIN-00014 University of Helsinki, Finland.

Received August 12, 1993; accepted in revised form December 3, 1993. 
effects of the salt alternative could be due either to the lowered intake of sodium chloride or increased intakes of potassium, magnesium and 1-lysine. We therefore conducted two sets of experiments. In the first experiment, regular salt and the salt alternative were supplemented at the same level. Hence, the concentration of sodium chloride in the diet was $43 \%$ lower in the salt alternative group. In the second experiment, regular salt was added at a $43 \%$ lower level than the salt alternative. Hence, in this experiment the dietary sodium chloride level was the same in both groups. Even though the present salt alternative contains considerably less potassium than salt substitutes which have produced hyperkalemia $(15,16)$, we paid special attention to potassium determinations.

\section{Materials and Methods}

\section{Experimental Animals and Diets \\ Experiment I}

Fifty-seven male stroke-prone spontaneously hypertensive rats (SHRSP) purchased from Møllegaards Breeding Centre, LI. Skensved, Denmark, were used in this study. At the beginning of the study, the nine-week-old rats were randomized into five subgroups to receive different diets for four weeks: 1) a control group $(n=10)$ receiving standard rat chow (Finnewos Aqua, Helsinki, Finland; $\mathrm{Na}$ $0.3 \%), 2)$ a high sodium chloride group without enalapril $(n=18)(6.0 \mathrm{~g}$ of $\mathrm{NaCl}$, Merck, Darmstadt, Germany, added to $94.0 \mathrm{~g}$ of the chow; $\mathrm{NaCl}$ $6 \%), 3)$ a salt alternative group without enalapril ( $n$ $=10)(6.0 \mathrm{~g}$ of the commercially available salt alternative Pansalt ${ }^{\circledR}$, Oriola Oy, Espoo, Finland added to $94.0 \mathrm{~g}$ of the chow; $\mathrm{NaCl} 3.4 \%$ ), 4) a high sodium chloride group with enalapril treatment $(n=$ 10) $(\mathrm{NaCl} 6 \%)$, and 5) a salt alternative group with enalapril $(n=10)(\mathrm{NaCl} 3.4 \%)$. The salt alternative used in the present study has the following composition: $\mathrm{NaCl} 57 \%, \mathrm{KCl} 28 \%, \mathrm{MgSO}_{4} .7 \mathrm{H}_{2} \mathrm{O} 12 \%, l-$ lysine hydrochloride $2 \%$, and anticaking agents $\left(\mathrm{MgCO}_{3}, \mathrm{SiO}_{2}\right) 1 \%$. Therefore, the sodium chloride concentration was $43 \%$ lower in the SA groups than in the regular salt groups. Enalapril (enalapril maleate, kindly donated by Merck, Sharp and Dohme Research Laboratories, Rahway, N.J., USA) was added at the level of $350 \mathrm{mg}$ enalapril per $\mathrm{kg}$ of dry weight of the chow to produce an average daily dose of approximately $30 \mathrm{mg}$ per $\mathrm{kg}$ body weight. The contents of sodium, potassium, magnesium and other nutrients in the different diets are given in Table 1. The rats had free access to tap water and chow. During the fourth week of the experiment, the rats were housed individually in metabolic cages. Feed intake was recorded and urine was collected over a 24-hour period. Rats were examined daily for survival and signs of stroke throughout the study. Assessment of stroke was based on the presence of evident and stable hemiplegia, akinesia, lethargy, and hyporesponsiveness according to the symptomatological classification described by Yamori et al. (17). The study was approved by the Animal Experimentation Commit- tee of the University of Helsinki, Finland.

\section{Experiment II}

Sixteen male SHRSP were used in this study. At the beginning of the study, the nine-week-old rats were randomized into two subgroups: 1) a moderately high sodium chloride group with enalapril $(n$ $=8)(3.4 \mathrm{~g}$ of $\mathrm{NaCl}$ added to $96.6 \mathrm{~g}$ of the chow; $\mathrm{NaCl} 3.4 \%$ ), and 2) a salt alternative group with enalapril $(n=8)(6.0 \mathrm{~g}$ of the salt alternative added to $94.0 \mathrm{~g}$ of the chow; $\mathrm{NaCl} 3.4 \%$ ). The content of sodium chloride in the chow was thereby adjusted to the same level in the two groups. Enalapril maleate was added at the level of $350 \mathrm{mg}$ enalapril per $\mathrm{kg}$ of dry weight of the chow to produce an average daily dose of approximately $30 \mathrm{mg}$ per $\mathrm{kg}$ body weight. Otherwise, Experiment II was performed in the same way as Experiment I.

\section{Measurement of Blood Pressure}

Systolic blood pressure of the pretrained rats was measured weekly using a tail cuff method (Blood pressure recorder, model no. $8002 \mathrm{e}, \mathrm{W}+\mathrm{W}$ electronics Inc., Basel, Switzerland). The same technician made all blood pressure measurements. Details of the procedure have been described earlier (13).

\section{Sample Preparation}

After the four-week experimental period, the rats were anesthetized with sodium pentobarbital $(65 \mathrm{mg}$ $/ \mathrm{kg}$ i.p.), the carotid artery was cannulated, and blood samples were drawn into chilled tubes on ice using EDTA as anticoagulant. The hearts were excised, the great vessels, atria and the free wall of the right ventricle were dissected, and the left ventricular mass (LVM) was measured. The left ventricular wet weight-to-body weight ratio was calculated as an index of left ventricular hypertrophy.

\section{Determination of Plasma Renin Activity}

Plasma renin activity was determined by using a radioimmunoassay (RIA) of angiotensin I, modified for rat plasma (18).

\section{Determination of Electrolyte Concentrations}

The concentrations of the elements sodium, potassium, phosphorus, magnesium, calcium and zinc in urine were determined by using a Baird PS-4 inductively-coupled plasma emission spectrometer (Baird Co, Bedford, M.A., USA) as described in detail elsewhere (19). For magnesium the intraassay imprecision was $1.5 \%$ and the interassay imprecision was $0.5 \%$. The intra-assay imprecision for the other elements was better than $3 \%$ and the interassay imprecision was not more than $5 \%$. The mean levels obtained for the NIST (National Institute of Standards, Washington, USA) $1577 \mathrm{~b}$ reference material were within $3.5 \%$ of NIST certified values. The concentrations of sodium and potassium in plasma were determined employing a standard ion selective electrode method using a Cobas Fara II random access analyzer (F.Hoffman-La Roche, Basel, Switzerland) according to the instructions of the manufacturer. The concentration of magnesium in plasma was determined by a spectroscopic 
Table 1. Contents of Sodium, Potassium, Magnesium and Other Nutrients in the Different Diets

\begin{tabular}{|c|c|c|c|c|}
\hline & & Control diet & Common salt diet & Salt alternative diet \\
\hline \multicolumn{5}{|l|}{ Mineral element } \\
\hline \multicolumn{5}{|l|}{ Sodium } \\
\hline Experiment I & & $0.3^{*}$ & $2.6^{*}$ & $1.6^{*}$ \\
\hline Experiment II & & & $1.6^{*}$ & $1.6^{*}$ \\
\hline Potassium & & $0.8^{*}$ & $0.8^{*}$ & $1.7^{*}$ \\
\hline Magnesium & & $0.2^{*}$ & $0.2^{*}$ & $0.27^{*}$ \\
\hline \multicolumn{5}{|c|}{ Other nutrients (contents common for all diets) } \\
\hline \multicolumn{2}{|l|}{ Mineral elements } & & $\mathrm{B}_{1}$ & $3 \mathrm{mg} / \mathrm{kg}$ \\
\hline Calcium & $1.0^{*}$ & & $\mathrm{~B}_{2}$ & $12 \mathrm{mg} / \mathrm{kg}$ \\
\hline Phosphorus & $0.75^{*}$ & & $\mathrm{~B}_{6}$ & $5 \mathrm{mg} / \mathrm{kg}$ \\
\hline Iron & $178 \mathrm{mg} / \mathrm{kg}$ & & $\mathrm{B}_{12}$ & $0.02 \mathrm{mg} / \mathrm{kg}$ \\
\hline Zinc & $115 \mathrm{mg} / \mathrm{kg}$ & & Calcium pantothenate & $10 \mathrm{mg} / \mathrm{kg}$ \\
\hline Manganese & $89 \mathrm{mg} / \mathrm{kg}$ & & Niacin & $40 \mathrm{mg} / \mathrm{kg}$ \\
\hline Copper & $18 \mathrm{mg} / \mathrm{kg}$ & & Choline chloride & $1,000 \mathrm{mg} / \mathrm{kg}$ \\
\hline Iodine & $2 \mathrm{mg} / \mathrm{kg}$ & & Major constituents & \\
\hline Cobalt & $1 \mathrm{mg} / \mathrm{kg}$ & & Water & $11.7^{*}$ \\
\hline Vitamins & & & Crude fat & $5.3^{*}$ \\
\hline A & $12,000 \mathrm{iu} / \mathrm{kg}$ & & Crude protein & $21.0^{*}$ \\
\hline $\mathrm{D}_{3}$ & $1,500 \mathrm{iu} / \mathrm{kg}$ & & Fiber & $2.8^{*}$ \\
\hline $\mathrm{E}$ & $63 \mathrm{mg} / \mathrm{kg}$ & & Carbohydrate & $52.2^{*}$ \\
\hline $\mathrm{K}_{1}$ & $0.25 \mathrm{mg} / \mathrm{kg}$ & & Ash & $7.0^{*}$ \\
\hline $\mathrm{K}_{3}$ & $10 \mathrm{mg} / \mathrm{kg}$ & & Metabolizable energy & $13.0 \mathrm{MJ} / \mathrm{kg}$ \\
\hline
\end{tabular}

${ }^{*}$ Values are expressed as $\%(\mathrm{~g} / 100 \mathrm{~g})$ of the dry weight of the pellets.

method using metallochromic dye, Camalgite (Sherwood Medical, St Louis, M.O., USA), and the Cobas Fara II. The intra-assay imprecision was $0.2 \%$ for sodium, $0.4 \%$ for potassium and $1.5 \%$ for magnesium, and the interassay imprecision was $0.5 \%$ for sodium, $0.65 \%$ for potassium and $4.5 \%$ for magnesium.

\section{Statistical Analysis}

Statistical analysis was carried out by one-way analysis of variance (ANOVA) supported by the Scheffe's test. Data for multiple observations over time were analyzed by two-way ANOVA with repeated measures for overall treatment effect, and the Scheffe's test was used for multiple pairwise comparisons of treatment groups at different times. The area under the curve (AUC) (blood pressure $v s$. time) of each individual rat in different treatment groups was also calculated mathematically by the methods outlined by Matthews et al. (20). The AUCs were then tested by ANOVA, supported by the Scheffe's test. Differences between means that had $p<0.05$ were considered significant. Statistical analysis of the mortality during the 28-day follow-up period was calculated by a $2 \times 2$ Table using Fisher exact test (2-tail). The data were analyzed using BMDP Statistical Software (Los Angeles, CA, USA). The results are expressed as means \pm SEM.

\section{Results}

\section{Experiment I}

Death-rate and Stroke

Five of the 18 SHRSP which were supplemented with regular salt died during the experiment. All of these rats suffered from clinically diagnosed stroke before death. By contrast, none of the 10 SHRSP receiving the salt alternative died or suffered from stroke. In the presence of the enalapril treatment, no deaths occurred and there was no evidence of stroke in the SHRSP supplemented either with regular salt or the salt alternative. The mortality in the regular salt group was significant as compared to the other groups (mortality within 28 days, $2 \times 2$ Table, high sodium chloride group vs. other groups combined, Fisher exact two-tail test, $p=0.002$ ).

Blood Pressure and Left Ventricular Hypertrophy

Supplementation of the diet with regular salt produced a marked further elevation of blood pressure as compared to the age-related increase in blood pressure of the control SHRSP (Fig. 1). Enalapril did not significantly affect the rise of blood pressure during supplementation with regular salt. The rats receiving the salt alternative diet showed no significant increase in blood pressure when compared to the control SHRSP. In the salt alternative supplemented rats with enalapril treatment the blood pressure was markedly decreased from the third study week onwards, and during the overall 4-week 
follow-up period, as indicated by decreased AUC (Fig. 1).

Regular salt produced left ventricular hypertrophy as indicated by a marked increase in the left ventricular wet weight-to-body weight ratio (Fig. 2). In the salt alternative supplemented rats, the left ventricular hypertrophy index was increased when compared to the control group, but decreased as

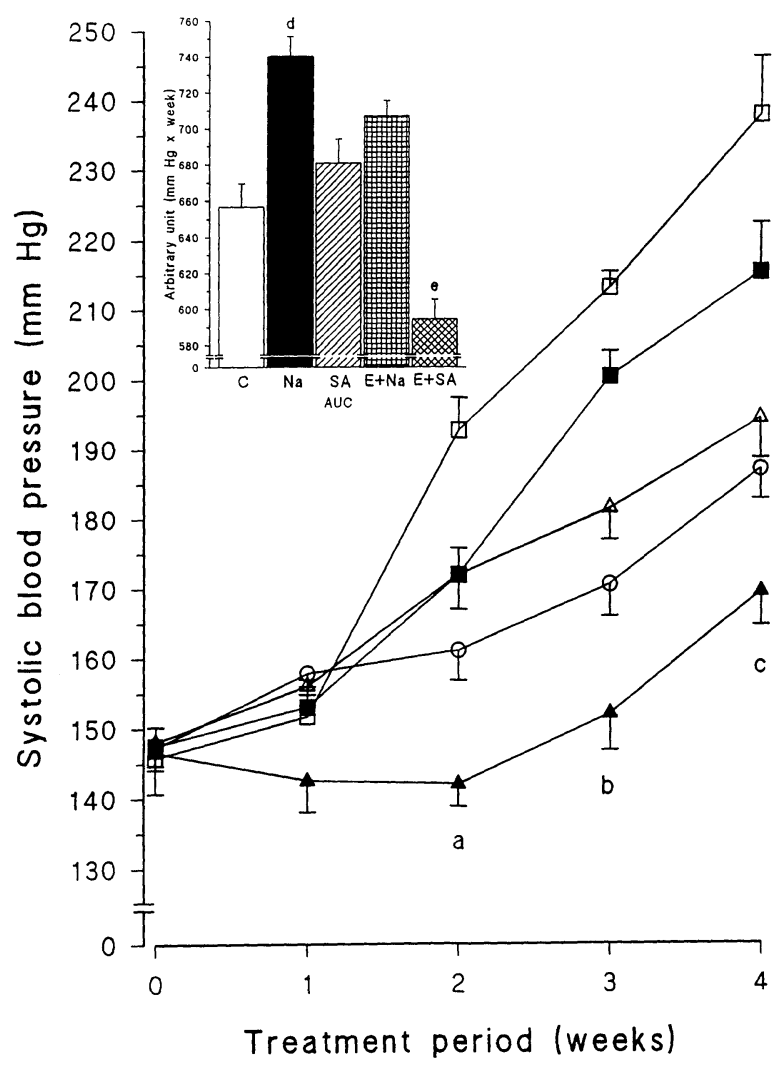

Fig. 1. Line plots show the blood pressure of stroke-prone spontaneously hypertensive rats during different diet and drug regimens. Open circles, controls on normal diet $(C, \mathrm{n}$ $=10)$; open squares, supplementation with regular salt $(\mathrm{Na}, \mathrm{n}=18-13)$; open triangles, supplementation with the salt alternative $(S A, \mathrm{n}=10)$; solid squares, regular salt with enalapril $(E+N a, \mathrm{n}=10)$; solid triangles, salt alternative with enalapril $(E+S A, \mathrm{n}=10)$. Repeated analysis of variance: between-subject effects, $\mathrm{p}<0.0001$; within-subject effects, time $\mathrm{p}<0.0001$, time-group interaction $\mathrm{p}<0.0001$. $a=N a$ vs. $C \mathrm{p}<0.01, N a$ vs. $E+S A \mathrm{p}<0.001, S A$ vs. $E+$ $S A \mathrm{p}<0.01, E+\mathrm{Na}$ vs. $E+S A \mathrm{p}<0.01 . b=N a$ vs. $C, S A$ and $E+S A \mathrm{p}<0.001, E+N a$ vs. $C$ and $E+S A \mathrm{p}<0.001$, $S A$ vs. $E+S A \mathrm{p}<0.001 . c=N a$ vs. $C, S A$ and $E+S A \mathrm{p}<$ $0.001, E+N a$ vs. $E+S A \mathrm{p}<0.001$. Bar graphs show area under the curve (AUC) (blood pressure versus time) in different treatment groups. Analysis of variance, $\mathrm{p}<$ 0.0001. $d=N a$ vs. $C$ and $E+S A$ p $<0.001, N a$ vs. $S A \mathrm{p}<$ 0.05. $e=E+S A$ vs. $C \mathrm{p}<0.05, E+S A$ vs. $S A$ and $E+N a$ $\mathrm{p}<0.001$. Vertical bars indicate $S E M$. compared to the regular salt group. Enalapril treatment did not inhibit the salt-induced left ventricular hypertrophy in the regular salt group. By contrast, in the enalapril-treated SHRSP of the salt alternative group, the left ventricular hypertrophy index did not differ from that of the control SHRSP.

Metabolic Variables and Indicators

There were no significant differences between the groups in the feed intake during the fourth study week (Table 2). All groups with salt supplementation had an increased 24-hour urine output. The 24hour urine output in the salt alternative group with or without enalapril, was smaller than that in the regular salt group. At the end of the follow-up period, the body weight of the rats in the regular salt group was slightly smaller than that in the other groups (Fig. 3). However, overall during the 4-week follow-up period no differences in the body weight gains between the different groups were found (Fig. $3)$. The calculated average daily dose of enalapril was $31.3 \pm 1.1 \mathrm{mg} / \mathrm{kg}$ body weight in the regular salt group and $34.6 \pm 3.3 \mathrm{mg} / \mathrm{kg}$ body weight in the salt alternative group $(p=0.364)$.

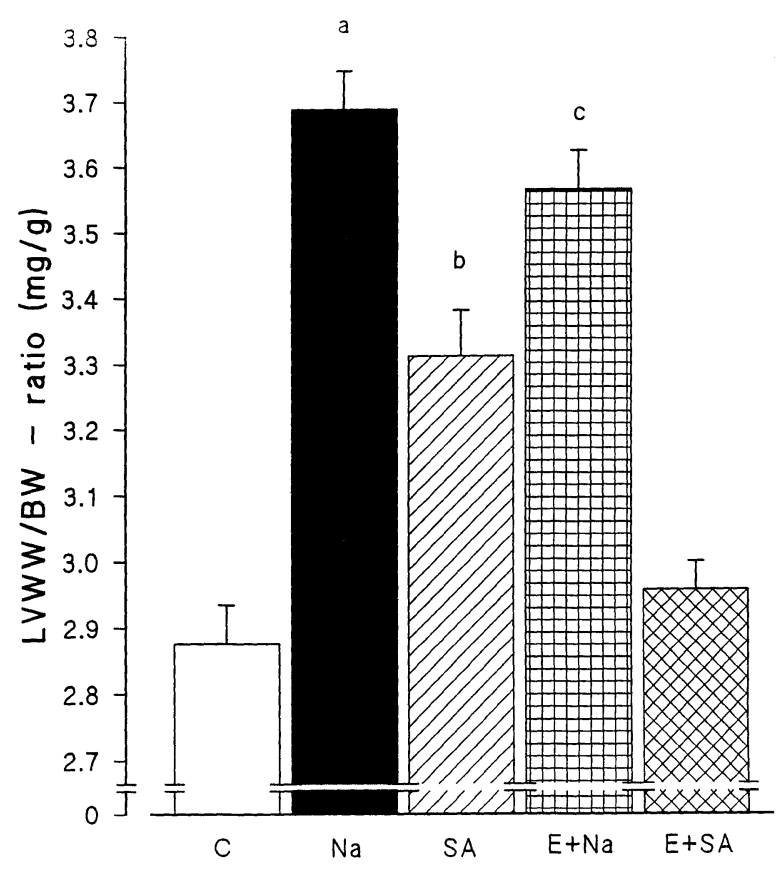

Fig. 2 Bar graphs show left ventricular hypertrophy index expressed as left ventricular wet weight (LVWW)-to-body weight $(B W)$ ratio of stroke-prone spontaneously hypertensive rats after four weeks on the different diet and drug regimens. $C$, controls on normal diet $(\mathrm{n}=10) ; \mathrm{Na}$, supplementation with regular salt $(\mathrm{n}=13) ; S A$, supplementation with the salt alternative $(\mathrm{n}=10) ; E+N a$, regular salt with enalapril $(\mathrm{n}=10) ; E+S A$, salt alternative with enalapril $(\mathrm{n}$ 10). Analysis of variance $\mathrm{p}<0.0001 . a=N a$ vs. $C$ and $E$ $+S A \mathrm{p}<0.001, N a$ vs. $S A \mathrm{p}<0.01 . b=S A$ vs. $C \mathrm{p}<0.01$, $S A$ vs. $E+S A \mathrm{p}<0.05 . c=E+N a$ vs. $C$ and $E+S A \mathrm{p}<$ 0.001 . Vertical bars indicate $S E M$. 
Urine Electrolytes

The 24-hour urinary excretion of sodium was increased in all groups with regular salt or salt alternative supplementation when compared to the control group (Table 2). In enalapril-treated SHRSP receiving the salt alternative, sodium excretion was smaller than in the corresponding regular salt group. The level of potassium in urine was increased in the salt alternative supplemented rats both with and without enalapril treatment. In the regular salt supplemented rats, both with and without enalapril, the level of potassium was decreased when compared to the controls. Magnesium excretion was increased in the salt alternative groups. Calcium excretion was markedly increased in all groups with salt supplementation. The excretion of phosphorus and zinc was markedly increased in the regular salt supplemented rats, both with and without enalapril treatment.

Plasma Electrolytes and Renin Activity

There were no differences between the groups in the plasma sodium and magnesium levels. The potassium level was decreased in the regular salt supplemented, enalapril-treated rats. The plasma renin activity was similar in the controls, in the regular salt supplemented and in the salt alternative supplemented groups without enalapril treatment (Table 3). Enalapril treatment increased the plasma renin activity to the same extent, approximately three-fold, in the regular salt and the salt alternative groups.

\section{Experiment II}

Death Rate and Stroke

None of the enalapril-treated SHRSP in experiment II died or showed any evidence of stroke during the 4-week follow-up period.

Blood Pressure and Left Ventricular Hypertrophy

The blood pressure in the moderately high sodium chloride group was higher than in the salt alternative group from the first to the third study week, and during the overall 4-week follow-up period

Table 2. 24-Hour Feed Consumption, Urine Volume and Urinary Excretion Rates of Various Mineral Elements of Stroke-Prone Spontaneously Hypertensive Rats after Three Weeks on the Different Diets and Drug Regimens

\begin{tabular}{|c|c|c|c|c|c|c|c|}
\hline & $\mathrm{C}$ & $\mathrm{Na}$ & $\mathrm{E}+\mathrm{Na}$ & SA & $E+S A$ & ANOVA & $\begin{array}{l}\text { Difference between } \\
\text { groups at } p<0.05\end{array}$ \\
\hline $\begin{array}{l}\text { Feed intake } \\
\text { (g/day) }\end{array}$ & $25.6 \pm 1.7$ & $20.1 \pm 1.1$ & $22.5 \pm 0.9$ & $22.3 \pm 1.3$ & $24.8 \pm 2.0$ & 0.045 & - \\
\hline $\begin{array}{l}\text { Urine } \\
\text { volume (ml/day) }\end{array}$ & $16.3 \pm 1.9$ & $65.2 \pm 2.8$ & $71.9 \pm 5.0$ & $47.1 \pm 1.9$ & $39.4 \pm 2.3$ & $<0.0001$ & $\begin{array}{l}\mathrm{C} \text { vs. } \mathrm{Na}, \mathrm{SA}, \mathrm{E}+\mathrm{Na} \\
\text { and } \mathrm{E}+\mathrm{SA} \mathrm{Na} \text { and } \mathrm{E}+ \\
\mathrm{NA} \text { vs. } \mathrm{SA} \text { and } \mathrm{E}+\mathrm{SA}\end{array}$ \\
\hline $\begin{array}{l}\text { sodium } \\
(\mathrm{mmol} / \text { day })\end{array}$ & $1.5 \pm 0.09$ & $13.1 \pm 0.7$ & $14.9 \pm 1.1$ & $11.1 \pm 0.8$ & $10.6 \pm 0.3$ & $<0.0001$ & $\begin{array}{l}\mathrm{C} v s . \mathrm{Na}, \mathrm{SA}, \mathrm{E}+\mathrm{Na} \\
\text { and } \mathrm{E}+\mathrm{SA} \mathrm{E}+\mathrm{Na} v s . \\
\mathrm{SA} \text { and } \mathrm{E}+\mathrm{SA}\end{array}$ \\
\hline $\begin{array}{l}\text { potassium } \\
(\mathrm{mmol} / \text { day })\end{array}$ & $2.81 \pm 0.18$ & $1.76 \pm 0.10$ & $1.83 \pm 0.13$ & $5.73 \pm 0.35$ & $5.72 \pm 0.20$ & $<0.0001$ & $\begin{array}{l}\mathrm{C} v s, \mathrm{Na}, \mathrm{SA}, \mathrm{E}+\mathrm{Na} \\
\text { and } \mathrm{E}+\mathrm{SA} \mathrm{Na} \mathrm{vs.} \mathrm{SA} \\
\text { and } \mathrm{E}+\mathrm{SA} \mathrm{E}+\mathrm{Na} v s . \\
\mathrm{SA} \text { and } \mathrm{E}+\mathrm{SA}\end{array}$ \\
\hline $\begin{array}{l}\text { magnesium } \\
(\mathrm{mmol} / \mathrm{day})\end{array}$ & $0.24 \pm 0.04$ & $0.27 \pm 0.01$ & $0.35 \pm 0.03$ & $0.41 \pm 0.03$ & $0.40 \pm 0.02$ & 0.0003 & $\begin{array}{l}\mathrm{C} \text { and } \mathrm{Na} v s . \mathrm{SA} \text { and } \mathrm{E} \\
+\mathrm{SA}\end{array}$ \\
\hline $\begin{array}{l}\text { phosphorus } \\
\text { (mmol/day) }\end{array}$ & $0.94 \pm 0.06$ & $1.10 \pm 0.05$ & $1.09 \pm 0.08$ & $0.80 \pm 0.05$ & $0.80 \pm 0.03$ & 0.0007 & $\begin{array}{l}\mathrm{Na} \text { and } \mathrm{E}+\mathrm{Na} v s . \mathrm{SA} \\
\text { and } \mathrm{E}+\mathrm{SA}\end{array}$ \\
\hline $\begin{array}{l}\text { calcium } \\
(\mathrm{mmol} / \text { day })\end{array}$ & $0.034 \pm 0.005$ & $0.17 \pm 0.009$ & $0.25 \pm 0.02$ & $0.16 \pm 0.02$ & $0.16 \pm 0.01$ & $<0.0001$ & $\begin{array}{l}\mathrm{C} v s . \mathrm{Na}, \mathrm{SA}, \mathrm{E}+\mathrm{Na} \\
\text { and } \mathrm{E}+\mathrm{SA} \mathrm{E}+\mathrm{Na} v s . \\
\mathrm{Na}, \mathrm{SA} \text { and } \mathrm{E}+\mathrm{SA}\end{array}$ \\
\hline $\begin{array}{l}\text { zinc } \\
(\mu \mathrm{mol} / \mathrm{day})\end{array}$ & $0.19 \pm 0.03$ & $0.48 \pm 0.08$ & $0.55 \pm 0.06$ & $0.41 \pm 0.02$ & $0.37 \pm 0.03$ & 0.001 & $\mathrm{C} v s . \mathrm{Na}$ and $\mathrm{E}+\mathrm{Na}$ \\
\hline
\end{tabular}

The control group $(\mathrm{C}, n=10)$ received standard rat chow $(\mathrm{Na} 0.3 \%)$. The chow of the high sodium chloride group (Na, $n=13)$ and that of the high sodium chloride + enalapril group $(\mathrm{E}+\mathrm{Na}, n=10$; enalapril mixed in the chow to produce an approximate daily dose of $30 \mathrm{mg} / \mathrm{kg}$ ) was supplemented with regular salt ( $6 \%$ sodium chloride). The chow of the salt alternative group (SA, $n=10)$ and that of the salt alternative + enalapril group $(\mathrm{E}+\mathrm{SA}, n=10$; enalapril as above) was supplemented with the salt alternative $\left(6 \%\right.$ Pansalt $\left.^{\circledR}\right)$. 


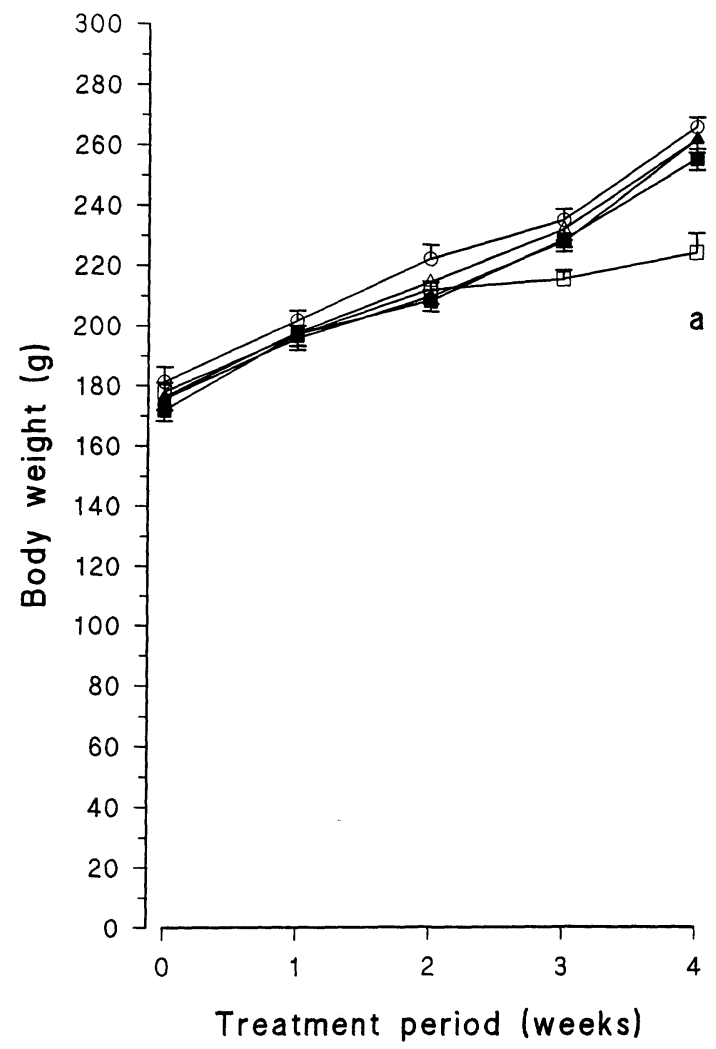

Fig. 3. Line plots show body weight of stroke-prone spontaneously hypertensive rats during different diet and drug regimens. Open circles, controls on normal diet $(C, \mathrm{n}$ $=10)$; open squares, supplementation with regular salt (Na, $\mathrm{n}=18-13)$; open triangles, supplementation with the salt alternative $(S A, \mathrm{n}=10)$; solid squares, regular salt with enalapril $(E+N a, \mathrm{n}=10)$; solid triangles, salt alternative with enalapril $(E+S A, \mathrm{n}=10)$. Repeated analysis of variance: between-subject effects, $\mathrm{p}=0.1068$; within-subject effects, time $\mathrm{p}<0.0001$, time-group interaction $\mathrm{p}<0.0001$. $a=N a$ vs. all other test groups, $\mathrm{p}<0.001$. Vertical bars indicate SEM.

(Fig. 4). The left ventricular hypertrophy index of the moderately high sodium chloride group was higher than that of the salt alternative group (Fig. 5).

The moderately high sodium chloride diet $(\mathrm{NaCl}$ $3.4 \%$ ) attenuated the cardiovascular effects of enalapril less than the high sodium chloride diet $(\mathrm{NaCl}$ $6.0 \%$ ) (area under the curve: blood pressure versus time $673 \pm 12$ vs. $707 \pm 9, p=0.031$; left ventricular hypertrophy: $3.064 \pm 0.027 \mathrm{mg} / \mathrm{g}$ vs. $3.563 \pm 0.059$ $\mathrm{mg} / \mathrm{g}, p<0.001$ ).

Metabolic Variables and Indicators

There were no differences between the groups in the feed intake (Table 4) or in the body weight gain (repeated ANOVA between-subject effects $p=$ 0.4699 ; within-subject effects, time $p<0.001$, timegroup interaction $p=0.4062$ ). There was no difference between the groups in the 24-hour urine out-

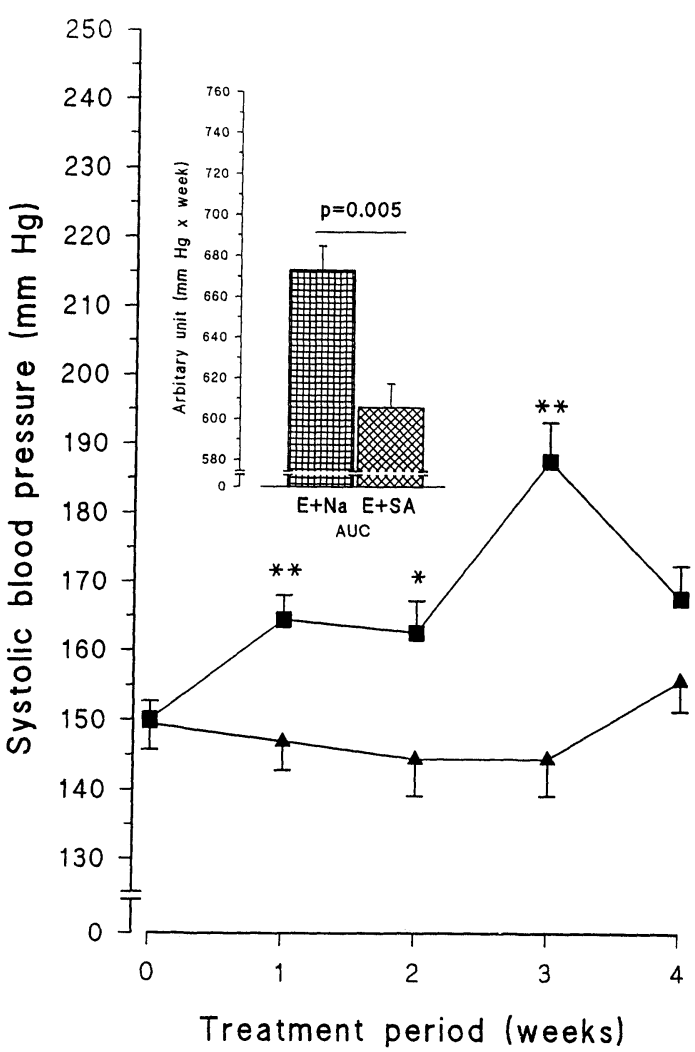

Fig. 4. Line plots show blood pressure of stroke-prone spontaneously hypertensive rats during different diet and drug regimens. Solid squares, moderate regular salt supplementation ( $\mathrm{NaCl} 3.4 \%)$ with enalapril $(E+\mathrm{Na}, \mathrm{n}=8)$; solid triangles, salt alternative (SA 6\%, corresponding to $3.4 \% \mathrm{NaCl})$ with enalapril $(E+S A, \mathrm{n}=8)$. Repeated analysis of variance between-subject effects, $\mathrm{p}=0.0099$; within-subject effects, time $\mathrm{p}<0.001$, time-group interaction $\mathrm{p}=0.0071 .{ }^{*} \mathrm{p}<0.05,{ }^{*} \mathrm{p}<0.01$. Area under the curve (AUC) (blood pressure vs. time) $\mathrm{p}=0.005$. Vertical bars indicate SEM

put (Table 4). The calculated average daily dose of enalapril was $34.6 \pm 0.9 \mathrm{mg} / \mathrm{kg}$ body weight in the regular salt group and $31.9 \pm 1.8 \mathrm{mg} / \mathrm{kg}$ body weight in the salt alternative group $(p=0.203)$.

Urine Electrolytes

There were no differences between the groups in the 24-hour urinary excretion of sodium, magnesium, calcium or zinc. In the salt alternative group, the excretion of potassium was higher and that of phosphorus was lower than in the regular salt group (Table 4).

Plasma Electrolytes and Renin Activity

The plasma renin activity was markedly higher and plasma potassium was slightly higher in the salt alternative group than in the regular salt group (Table 3). 
Table 3. The Plasma Levels of Sodium, Potassium and Magnesium and Plasma Renin Activity of Stroke-Prone Spontaneously Hypertensive Rats at the End of the Study

\begin{tabular}{|c|c|c|c|c|c|c|c|}
\hline Experiment I & $\mathrm{C}$ & $\mathrm{Na}$ & $\mathrm{E}+\mathrm{Na}$ & SA & $\mathrm{E}+\mathrm{SA}$ & ANOVA & $\begin{array}{l}\text { Difference between } \\
\text { groups at } p<0.05\end{array}$ \\
\hline Sodium $(\mathrm{mmol} / \mathrm{l})$ & $138.8 \pm 0.4$ & $136.8 \pm 0.9$ & $137.7 \pm 0.3$ & $137.7 \pm 0.6$ & $138.5 \pm 0.4$ & 0.1448 & - \\
\hline Potassium $(\mathrm{mmol} / \mathrm{l})$ & $3.49 \pm 0.06$ & $3.31 \pm 0.08$ & $3.08 \pm 0.04$ & $3.41 \pm 0.11$ & $3.33 \pm 0.08$ & 0.0225 & $\mathrm{C} v s . \mathrm{E}+\mathrm{Na}$ \\
\hline Magnesium (mmol/l) & $0.85 \pm 0.008$ & $0.82 \pm 0.02$ & $0.81 \pm 0.02$ & $0.82 \pm 0.02$ & $0.83 \pm 0.01$ & 0.4547 & - \\
\hline $\begin{array}{l}\text { Renin activity } \\
\text { (ng Ang I/ml/h) }\end{array}$ & $7.2 \pm 1.1$ & $7.3 \pm 1.0$ & $20.7 \pm 1.0$ & $7.1 \pm 1.4$ & $19.9 \pm 3.0$ & $<0.0001$ & $\begin{array}{l}\mathrm{C}, \mathrm{Na} \text { and } \mathrm{SA} v s . \\
\mathrm{E}+\mathrm{Na} \text { and } \mathrm{E}+\mathrm{SA}\end{array}$ \\
\hline Experiment II & $\mathrm{E}+\mathrm{Na}$ & $\mathrm{E}+\mathrm{SA}$ & $\begin{array}{c}t \text {-Test } \\
(p \text {-value })\end{array}$ & & & & \\
\hline Sodium $(\mathrm{mmol} / \mathrm{l})$ & $138.6 \pm 0.3$ & $137.6 \pm 0.4$ & 0.096 & & & & \\
\hline Potassium $(\mathrm{mmol} / \mathrm{l})$ & $3.44 \pm 0.03$ & $3.60 \pm 0.05$ & 0.022 & & & & \\
\hline Magnesium (mmol/l) & $0.82 \pm 0.02$ & $0.82 \pm 0.02$ & 0.799 & & & & \\
\hline $\begin{array}{l}\text { Renin activity } \\
\text { (ng Ang } \mathrm{I} / \mathrm{ml} / \mathrm{h} \text { ) }\end{array}$ & $13.6 \pm 3.6$ & $31.2 \pm 4.2$ & 0.006 & & & & \\
\hline
\end{tabular}

In Experiment $\mathrm{I}$, the control group $(\mathrm{C}, n=10)$ received standard rat chow $(\mathrm{Na} 0.3 \%)$. The chow of the high sodium chloride group $(\mathrm{Na}, n=13)$ and that of the high sodium chloride + enalapril group $(\mathrm{E}+\mathrm{Na}, n=10$; enalapril mixed in the chow to produce an approximate daily dose of $30 \mathrm{mg} / \mathrm{kg}$ ) was supplemented with regular salt (6\% sodium chloride). The chow of the salt alternative group $(\mathrm{SA}, n=10)$ and that of the salt alternative +enalapril group $(\mathrm{E}+\mathrm{SA}, n=10 ;$ enalapril as above) was supplemented with $6 \%$ of the salt alternative (Pansalt ${ }^{\circledR}$ ).

In Experiment II, both groups received enalapril orally, at a dose of approximately $30 \mathrm{mg} / \mathrm{kg} / \mathrm{day}$, for four weeks. The chow of one group $(\mathrm{E}+\mathrm{Na}, n=8)$ was supplemented with regular salt $(3.4 \%$ sodium chloride), and the chow of the other group $(\mathrm{E}+\mathrm{SA}, n=8)$ with the salt alternative $\left(6 \%\right.$ Pansalt $^{\circledR}$, corresponding to $3.4 \%$ sodium chloride).

\section{Discussion}

An increased intake of sodium chloride (regular salt) produced a marked further elevation of blood pressure and increase in left ventricular hypertrophy as compared to the age-related increases in control SHRSP. The increased intake of sodium chloride also produced significant mortality of SHRSP during the four-week experiment. These effects of regular salt are in agreement with previous findings in SHR and SHRSP $(3,13,14,21)$. By contrast, the sodiumreduced, potassium-, magnesium-, and $l$-lysine-enriched salt alternative, at the same intake level as regular salt, neither caused any mortality nor induced any significant rise in blood pressure. It also caused significantly less left ventricular hypertrophy than regular salt did. Our previous studies $(13,14)$, using higher levels of the salt alternative, demonstrated that the increased intakes of potassium and/ or magnesium and $l$-lysine from the salt alternative protected against the harmful effects of the increased intakes of sodium chloride. Tobian (22) has reported a protective effect of potassium supplementation against stroke and mortality in saltloaded rats.

Previous studies have suggested that the detrimental effects of a high intake of sodium chloride could have been mediated mainly by elevated blood volume and cardiac output and by elevated sympathetic nervous system activity (23). Normalization of sodium and water balance and sympathetic nervous activity appeared to explain, at least in part, the protection against the harmful effects of the increased intake of sodium chloride by the increased intakes of potassium and/or magnesium and $l$-lysine from the salt alternative $(13,14)$. Potassium supplementation also protected against dysfunction of endothelial cells in stroke-prone spontaneously hypertensive rats (24) and preserved endothelial function in Dahl rats during a high sodium chloride diet (25). Moreover, Watson et al. have shown (26) that magnesium sulfate amplifies the release of prostacyclin by human umbilical vein endothelial cells in a dose-dependent manner. However, the smaller intake of sodium chloride in the salt alternative group may also have contributed to the favorable effect.

Enalapril treatment did not produce any significant lowering of blood pressure and it did not decrease the left ventricular hypertrophy in SHRSP receiving the high sodium chloride diet, while the moderately high sodium chloride diet antagonized slightly less the cardiovascular effects of enalapril. However, in spite of the lack of effect on these cardiovascular variables, enalapril protected against stroke and mortality. In agreement with our observation, Stier and coworkers (27) also found that during a high intake of sodium chloride, enalapril treatment decreased SHRSP mortality. The mechanism of this protective effect of ACEI is not 
clear.

In the present study chronic treatment with enalapril produced a remarkable antihypertensive effect in SHRSP receiving the salt alternative supplementation. The left ventricular hypertrophy also remained at the same level as in control SHRSP. Pre-

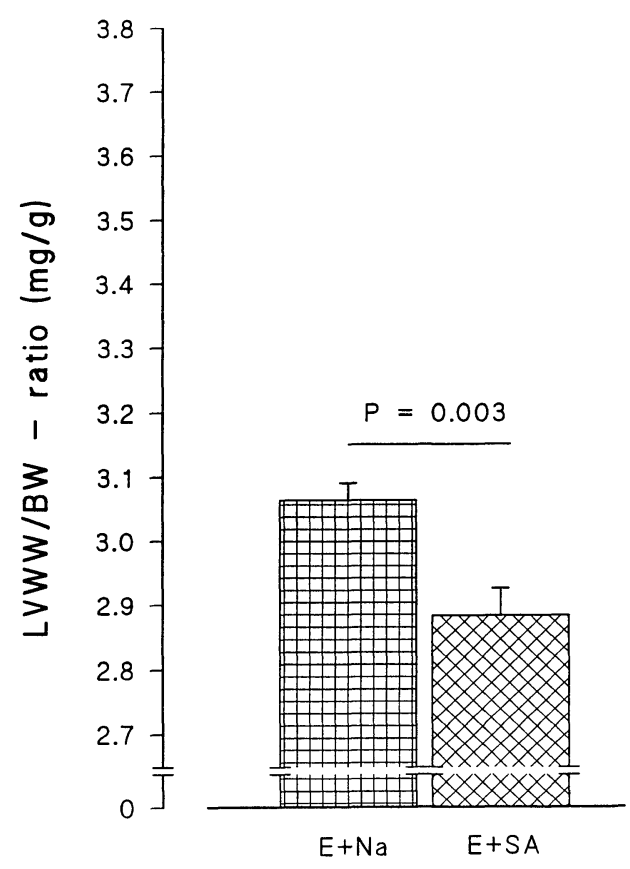

Fig. 5. Bar graphs show left ventricular hypertrophy index expressed as left ventricular wet weight ( $L V W W)$-tobody weight $(B W)$ ratio of stroke-prone spontaneously hypertensive rats after four weeks on the different diet and drug regimens. $\mathrm{E}+\mathrm{Na}$, moderate regular salt supplementation $(\mathrm{NaCl} 3.4 \%)$ with enalapril $(\mathrm{n}=8) ; E+S A$, salt alternative ( $\mathrm{SA} 6 \%$, corresponding to $3.4 \% \mathrm{NaCl}$ ) with enalapril $(\mathrm{n}=8)$. Vertical bars indicate SEM. vious studies have shown that ACEIs lower blood pressure and decrease left ventricular hypertrophy during a relatively low-sodium diet $(2,27-29)$. The diuretic effect of potassium supplementation (30) may have contributed to the beneficial effect of the salt alternative during enalapril treatment. ACEI treatment has been shown to improve the endothelium-dependent vascular relaxation in SHR by increasing the production of endothelium-derived relaxing factor(s) and by preventing the degradation of bradykinin liberated from the endothelial cells (31-33). In agreement with these studies, we found recently (34) that in SHRSP ramipril improved vascular relaxation during a low-sodium diet. The vascular relaxation enhancing effect of ramipril was blocked by regular salt supplementation (34). However, during the salt alternative supplemented diet (sodium chloride intake adjusted to the same level) the vascular relaxation enhancing effect of ramipril was only slightly attenuated (34). Hence, changes in vascular reactivity may also explain the hypertensive effect of sodium chloride and the beneficial effects of potassium, magnesium and $l$-lysine.

It has been suggested that enalapril treatment might increase the risk of hyperkalemia, at least in patients taking supplemental potassium or a potassium-sparing diuretic (2). However, the present salt alternative did not cause hyperkalemia, neither alone nor in combination with enalapril treatment.

The inhibitory effect of a high intake of sodium chloride on the antihypertensive effect of ACEI is consistent with previous observations $(2,29,35)$. It has been suggested that the resistance towards the effects of ACEI results from salt-induced inhibition in the activity of the renin-angiotensin-aldosterone system (2). However, neither in the regular salt nor in the salt alternative supplemented SHRSP the increased intake of sodium chloride affected plasma renin activity (PRA). Furthermore, in the presence of enalapril treatment, PRA was increased to the

Table 4. 24-Hour Feed Consumption, Urine Volume and Urinary Excretion Rates of Various Mineral Elements of Stroke-Prone Spontaneously Hypertensive Rats after Three Weeks on the Different Diet and Drug Regimens.

\begin{tabular}{lccc}
\hline & E+Na & E+SA & $\begin{array}{c}t \text {-Test } \\
(p \text {-value })\end{array}$ \\
\hline Feed intake intake (g/day) & $23.9 \pm 0.6$ & $22.4 \pm 1.2$ & 0.271 \\
Urine & $41.9 \pm 1.1$ & $36.9 \pm 3.5$ & 0.214 \\
volume (ml/day) & & & \\
sodium (mmol/day) & $11.6 \pm 0.9$ & $10.6 \pm 0.4$ & 0.384 \\
potassium (mmol/day) & $2.82 \pm 0.23$ & $5.87 \pm 0.23$ & $<0.001$ \\
magnesium (mmol/day) & $0.38 \pm 0.03$ & $0.45 \pm 0.03$ & 0.119 \\
phosphorus (mmol/day) & $1.50 \pm 0.07$ & $0.99 \pm 0.06$ & $<0.001$ \\
calcium (mmol/day) & $0.16 \pm 0.02$ & $0.15 \pm 0.01$ & 0.842 \\
zinc $(\mu$ mol/day) & $0.30 \pm 0.03$ & $0.33 \pm 0.02$ & 0.285 \\
\hline
\end{tabular}

Both groups received enalapril orally, at a dose of approximately $30 \mathrm{mg} / \mathrm{kg} / \mathrm{day}$, for four weeks. The chow of one group $(\mathrm{E}+\mathrm{Na}, n=8)$ was supplemented with regular salt $(3.4 \%$ sodium chloride chloride), and the chow of the other group ( $\mathrm{E}$ $+\mathrm{SA}, n=8)$ with the salt alternative $\left(6 \%\right.$ Pansalt $^{\circledR}$, corresponding to $3.4 \%$ sodium chloride). 
same extent in the regular salt and in the salt alternative supplemented SHRSP. Hence, PRA does not appear to explain the marked improvement of the effects of enalapril by the salt alternative in comparison to regular salt.

The lack of suppression in PRA by the increased intake of sodium chloride would, at first sight, appear rather surprising. However, Leenen and Toal (36) found that in SHR the maximum suppression of PRA that could be attained by dietary salt, was produced at the level of $101 \mu \mathrm{mol}(0.23 \%)$ sodium per gram rat chow. The control diet in our experiment contained sodium at the level of $0.3 \%$ which corresponds to $130 \mu \mathrm{mol} / \mathrm{g}$ rat chow. At corresponding dietary sodium levels, and Toal. (36) found similar low PRA in SHR as we did in SHRSP. At lower dietary sodium levels, Leenen and Toal. (36) found a progressive rise in PRA with decreasing sodium intake. Moreover, at the low dietary sodium level of $9 \mu \mathrm{mol} / \mathrm{g}$ rat chow, the development of spontaneous hypertension was prevented. These findings indicate that both SHR and SHRSP are very sensitive both to the PRA suppressing and the hypertensive effects of sodium.

The lack of suppression of PRA by regular salt supplementation could also result from malignant hypertension and renal lesions associated with a paradoxical rise in PRA, as suggested by Volpe et al. (37). However, we did not find any pathologically high PRA levels in the regular salt group, and there was not any difference in PRA between the regular salt and the salt alternative groups in the present study.

While effects on the circulating renin-angiotensinaldosterone system do not explain the beneficial influence of the salt alternative on the effects of enalapril, our findings do not exclude the possibility that there may have been differences between the regular salt and the salt alternative groups in reninangiotensin or kinin systems in the myocardium and other tissues. There is a lot of evidence to suggest that angiotensin II is involved in the production of myodardial (38-44) and vascular wall hypertrophy (45). Reduction of myocardial tissue angiotensin II by chronic treatment with ACEI in SHR has been reported (46). Enalapril treatment also suppressed the accumulation of elastin and collagen in the cardiovascular tissues of growing rats (47). ACE inhibition also increases the levels of bradykinin which appears to give protection against the development of cardiovascular hypertrophy (32).

Supplementation of SHRSP with regular salt or the salt alternative produced a five-fold increase in the urinary calcium excretion, both in the absence and in the presence of enalapril treatment. This finding confirms the results of previous studies demonstrating a rise in urinary calcium excretion with increasing intake of sodium chloride both in man and animals (48). Since the calciuric effect was similar in the regular salt and the salt alternative supplemented groups, it does not explain the difference in the enalapril-induced cardiovascular effects between the groups. However, our finding lends furth- er support to the suggestion that a high intake of salt may contribute to the development of osteoporosis (48).

In conclusion, the present sodium-reduced, potassium- and magnesium-enriched salt alternative was virtually devoid of the hypertensive and cardiac hypertrophy producing effects, typical of regular salt. Replacement of regular salt in the diet by the salt alternative remarkably improved the cardiovascular effects of enalapril. This effect was mainly due to increased intake of potassium and/or magnesium and $l$-lysine. The present salt alternative with a moderate content of potassium did not produce hyperkalemia, even when combined with ACEI treatment.

\section{Acknowledgments}

This study was supported by grants from the Academy of Finland, the Yrjö Jahnsson Foundation and the Sigrid Jusélius Foundation. The gift of enalapril maleate from Merck, Sharp and Dohme Research Laboratories (Rahway, NJ, USA) is gratefully acknowledged. We thank Professor Frej Fyhrquist, M.D., for the plasma renin activity measurements, and Ms. Pirkko Olkkonen, Ms. Toini Siiskonen, Ms. Aila Urjansson and Miss Remi Hakama for providing excellent technical assistance.

\section{References}

1. Law MR, Frost CD, Wald NJ: By how much does dietary salt reduction lower blood pressure? I-analysis of observational data among populations. $\mathrm{Br}$ Med $J$ 1991; 302: 811-815.

2. Waeber B, Nussberger J, Brunner HR: Angiotensinconverting-enzyme inhibitors in hypertension, in Brenner BM, Laragh JH (eds): Hypertension: pathophysiology, diagnosis, and management. New York, Raven Press, Ltd., 1990, pp 2209-2232.

3. Tobian L: Potassium and sodium in hypertension: The Volhard lecture. J Hypertens 1988; 6 (suppl): 12-24.

4. Cappucio FP, MacGregor GA: Does potassium supplementation lower blood pressure?: a meta-analysis of published trials. J Hypertens 1991; 9: 465-473.

5. Khaw K-T, Barrett-Connor E: Dietary potassium and stroke-associated mortality - a 12 year prospective population based study. $J$ Hypertens 1986; 4: 794-798.

6. Karppanen H: Epidemiologic evidence for considering magnesium deficiency as a risk factor for cardiovascular diseases. Magnesium Bull 1990; 12: 80-86.

7. Lind L, Lithell $\mathrm{H}$, Pollare $\mathrm{T}$, Ljunghall $\mathrm{S}$ : Blood pressure response during long-term treatment with magnesium is dependent on magnesium status: a double-blind placebo-controlled study in essential hypertension and in subjects with high-normal blood pressure. Am J Hypertens 1991; 4: 674-679.

8. Altura BM, Altura BT: Role of magnesium in the pathogenesis of hypertension: relationship to its actions on cardiac and vascular smooth muscle, in Laragh JH, Brenner BM (eds): Hypertension: Pathophysiology, Diagnosis and Management. New York, Raven Press, 1990, pp 1003-1025.

9. Sjögren A, Edvinsson L, Fallgren B: Magnesium de- 
ficiency in coronary artery disease and cardiac arrhytmias. J Int Med 1989; 226: 213-222.

10. Frost CD, Law MR, Wald NJ: By how much does dietary salt reduction lower blood pressure? II Analysis of observational data within populations. $\mathrm{Br}$ Med J 1991; 302: 815-818.

11. Law MR, Frost CD, Wald NJ: By how much does dietary salt reduction lower blood pressure? III Analysis of data from trials of salt reduction. $\mathrm{Br} \mathrm{Med}$ J 1991; 302: 819-824.

12. Jula A, Rönnemaa T, Rastas M, Karvetti RL, Mäki $\mathrm{J}$ : Long-term nonpharmacological treatment for mild to moderate hypertension. J Int Med 1990; 227: 413-421.

13. Mervaala EMA, Himberg J-J, Laakso J, Tuomainen $\mathrm{P}$, Karppanen $\mathrm{H}$ : Beneficial effects of a potassiumand magnesium-enriched salt alternative. Hypertension 1992; 19: 535-540.

14. Karppanen $\mathrm{H}$ : New oral salt in treatment of high blood pressure. Magnesium 1989; 8: 274-287.

15. McCaughan D: Hazards of non-prescription potassium supplements. Lancet 1984; 1: 513.

16. Hoyt RE: Hyperkalemia due to salt substitutes. JAMA 1986; 256: 1726.

17. Yamori Y, Horie R, Akiguchi I, Kihara M, Nara Y, Lovenberg W: Symptomatological classification in the development of stroke in stroke-prone spontaneously hypertensive rats. Jpn Circ J 1982; 46: 274-283.

18. Tikkanen I, Fyhrquist F, Puutula-Räsänen L: Enzyme inhibitors for renin assay in rat plasma. Clin $\mathrm{Sci}$ 1980; 59: 381-383.

19. Laakso JT, Tikkanen H, Michelsson J-E: Element concentrations in normal and immobilization-induced necrotic rabbit muscles. Trace Elem Med 1991; 8: 34-42.

20. Matthews JNS, Altman DG, Campbell MJ, Royston P: Analysis of serial measurements in medical research. Br Med J 1990; 300: 230-235.

21. Oparil S, Meng QC, Chen Y-F, Yang R-H, Jin H, Wyss JM: Genetic basis of NaCl-sensitive hypertension. J Cardiovasc Pharmacol 1988; 12: S56-S69.

22. Tobian L: The protective effects of a high-potassium diets in hypertension, and the mechanisms by which high- $\mathrm{NaCl}$ diets produce hypertension: a personal view, in Laragh $\mathrm{JH}$, Brenner BM (eds): Hypertension: Pathophysiology, Diagnosis, and Management. New York, Raven Press, Ltd., 1990, pp 49-61.

23. Muntzel M, Drucke T: A comprehensive review of the salt and blood pressure relationship. Am J Hypertens 1992; 5: S1-S42

24. Sugimoto T, Tobian L, Ganguli MC: High potassium diets protect against dysfunction of endothelial cells in stroke-prone spontaneously hypertensive rats. Hypertension 1988; 11: 579-585.

25. Sudhir K, Kurtz TW, Yock PG, Connolly AJ, Morris $\mathrm{RC} \mathrm{Jr}$ : Potassium preserves endothelial function and enhances aortic compliance in Dahl rats. Hypertension 1993; 22: 315-322

26. Watson KV, Moldow CF, Ogburn,PL, Jacob HS Magnesium sulfate: rationale for its use in preeclampsia. Proc Natl Acad Sci 1986; 83: 1075-1078.

27. Stier CT Jr, Benter IF, Ahmad S, et al: Enalapril prevents stroke and kidney dysfunction in salt-loaded stroke-prone spontaneously hypertensive rats. Hypertension 1989; 13: 115-121.

28. Richer C, Doussau M-P, Giudicelli J-P: MK 421 and prevention of genetic hypertension development in young spontaneously hypertensive rats. Eur J Pharmacol 1982; 79: 23-29.

29. MacGregor GA, Markandu ND, Singer DR, Cap- puccio FP, Shore AC, Sagnella GA: Moderate sodium restriction with angiotensin converting enzyme inhibitor in essential hypertension: a double blind study. $\mathrm{Br}$ Med J 1987; 294: 531-534.

30. Young DB, McCaa RE, Pan-Y-J, Guyton AC: The natriuretic and hypotensive effects of potassium. Circ Res 1976; 38 (suppl 2): 84-89.

31. Clozel M, Kuhn H, Hefti F: Effects of angiotensin converting enzyme inhibitors and of hydralazine on endothelial function in hypertensive rats. Hypertension 1990; 16: 532-540.

32. Wiemer G, Schölkens BA, Becker RHA, Busse R: Ramiprilat enhances endothelial autacoid formation by inhibiting breakdown of endothelium-derived bradykinin. Hypertension 1991; 18: 558-563.

33. Arvola P, Ruskoaho H, Wuorela H, Pekki A, Vapaatalo H, Pörsti I: Quinapril treatment and arterial smooth muscle responses in spontaneously hypertensive rats. $\mathrm{Br} J$ Pharmacol 1993; 108: 980-990.

34. Mervaala EMA, Paakkari I, Laakso J, et al: Replacement of regular salt by a novel potassium-and magnesium-enriched salt alternative improves the cardiovascular effects of ramipril. $\mathrm{Br} J$ Pharmacol 1994 (in press)

35. Fernandez D, Bolli P, Snedden W, Vasdev S, Fernandez PG: Modulation of left ventricular hypertrophy by dietary salt and inhibition of angiotensin converting enzyme. J Hypertens 1988; 6 (suppl 4): S145-S147.

36. Leenen FHH, Toal CB: Dietary sodium restriction and the renin-angiotensin system in young spontaneously hypertensive rats. J Hypertens 1989; 7 : 57-61.

37. Volpe M, Camargo MJF, Mueller FB, et al: Relation of plasma renin to end organ damage and to protection of $\mathrm{K}^{+}$feeding in stroke-prone hypertensive rats. Hypertension 1990; 15: 318-326

38. Hall C, Karlberg BE: Plasma concentration of angiotensin II and aldosterone during acute left ventricular failure in the dog. Res Exp Med 1986; 186: 387-395.

39. Lindpaintner K, Ganten $\mathrm{D}$ : The cardiac reninangiotensin system: an appraisal of present experimental and clinical evidence. Circ Res 1991; 68: 905-921.

40. Schunkert H, Dzau VJ, Tang SS, Hirsch AT, Apstein CS, Lorell $\mathrm{BH}$ : Increased rat cardiac angiotensin converting enzyme activity and mRNA expression in pressure overload left ventricular hypertrophy. Effects on coronary resistance, contractility, and relaxation. J Clin Invest 1990; 86: 1913-1920.

41. Brilla CG, Janicki JS, Weber KT: Cardiopreparative effects of lisinopril in rats with genetic hypertension and left ventricular hypertrophy. Circulation 1991; 83: $1771-1779$.

42. Childs TJ, Adams MA, Mak AS: Regression of cardiac hypertrophy in spontaneously hypertensive rats by enalapril and the expression of contractile proteins. Hypertension 1990; 16: 662-668.

43. Clozel J-P, Kuhn H, Hefti F: Effects of chronic ACE inhibition on cardiac hypertrophy and coronary vascular reserve in spontaneously hypertensive rats with developed hypertension. J Hypertens 1989; 7: 267-275

44. Pfeffer JM, Pfeffer MA, Mirsky I, Braunwald E: Regression of left ventricular hypertrophy and prevention of left ventricular dysfunction by captopril in the spontaneously hypertensive rat. Proc Natl Acad Sci USA 1982; 79: 3310-3314. 
45. Kato H, Suzuki H, Tajima S, et al: Angiotensin II stimulates collagen synthesis in cultured vascular smooth muscle cells. J Hypertens 1991; 9: 17-22.

46. Nagano M, Higaki J, Mikami H, et al: Converting enzyme inhibitors regressed cardiac hypertrophy and reduced tissue angiotensin II in spontaneously hypertensive rats. J Hypertens 1991; 9: 595-599.
47. Keeley FW, Elmoselhi A, Leenen FH: Enalapril suppresses normal accumulation of elastin and collagen in cardiovascular tissues of growing rats. $\mathrm{Am} J$ Physiol 1992; 262 (4 Pt 2): H1013-H1021.

48. Shortt C, Flynn A: Sodium-calcium inter-relationships with specific reference to osteoporosis. Nutr Res Rev 1990; 3: 101-115. 